\title{
THE EFFECTIVENESS OF THE APPLICATION OF ARTICULATE STORYLINE 3 LEARNING OBJECT ON STUDENT COGNITIVE ON BASIC COMPUTER SYSTEM COURSES
}

\author{
I Gede Partha Sindu' ${ }^{1 *}$, Gede Saindra Santyadiputra ${ }^{1}$, Agus Aan Jiwa Permana ${ }^{1}$ \\ ${ }^{1}$ Universitas Pendidikan Ganesha \\ Jl. Udayana No.11, Banyuasri, Buleleng, Bali 81116, Indonesia
}

\begin{abstract}
This study aimed to determine the effectiveness of applying learning objects based on Articulate Storyline 3 on student cognitive competence in the Basic Computer System course in the Informatics Engineering Education Study Program at the Ganesha University of Education. This type of research was descriptive quantitative with a pre-experimental research design involving one experimental class. The populations used in this study were all semester 1 students of the Informatics Engineering Education study program in the Basic Computer Systems course in the odd semester of the 2020-2021 academic year. Random sampling was using a simple random sampling technique. The average pretest result was 57.12, and the posttest average is 79.81. The paired pretestposttest $t$-test resulted in the Sig. equal to 0.000, which indicates that there is a significant difference in the average pretest and posttest results. The percentage of student responses to the learning model is 64.19. This shows that self-confidence in learning objects based on Articulate Storyline 3 on student cognitive abilities "Very Practical". The results of the N-Gain value showed a proportion of $60 \%$. It can be said that the application of learning objects based on Articulate Storyline 3 has a significant effect on the cognitive abilities of the students, cognitive ability increases quite effective, and the category of student response is very positive.
\end{abstract}

Keywords: learning objects, articulate storyline, basic computer system

How to cite: Sindu, I., Santyadiputra, G., \& Permana, A. (2020). The effectiveness of the application of Articulate Storyline 3 learning object on student cognitive on Basic Computer $\begin{array}{llll}\text { System } \quad \text { courses. Jurnal Pendidikan } \quad \text { Vokasi, } & \text { 10(3), }\end{array}$ doi:https://doi.org/10.21831/jpv.v10i3.36094

*Corresponding Author: I Gede Partha Sindu partha.sindu@undiksha.ac.id

- Department of Informatics Engineering, Faculty of Engineering and Vocation, Universitas Pendidikan Ganesha Jl. Udayana No.11, Banyuasri, Buleleng, Bali 81116, Indonesia 


\section{INTRODUCTION}

The learning system in the industrial era 4.0 makes it easier for people to access learning information. Easy access to learning information cannot be separated from the use of network technology and information technology. One of the many ways to utilize network technology and information technology for the development of learning systems in university is online learning for higher education. The initiator of this system is the Ministry of Education and Culture of the Republic of Indonesia. Since 2014 the Directorate of Learning and Student Affairs, the Directorate General of Higher Education has developed the Online Learning System or Sistem Pembelajaran Daring (SPADA) program. The Indonesian SPADA program is basically an implementation of Law of the Republic of Indonesia Number 20 of 2003 concerning the National Education System, Law of the Republic of Indonesia No. 12 of 2012 concerning Higher Education, and the Regulation of the Minister of Education and Culture No. 109 of 2013 concerning the Implementation of Distance Education in Higher Education. The Regulation of the Minister of Education and Culture Number 109 of 2013 states that one of the scope of distance education is at the courses level. One of the goals of the Indonesian SPADA program is to increase equitable access to quality learning in Higher Education. According to Mustofa et al. (2019), the online learning in higher education has a positive contribution to suppressing disparities in the quality of higher education institutions in Indonesia. The online lecture system provides a more comprehensive understanding than conventional systems, because the material is displayed digitally and in an animated form.

Universitas Pendidikan Ganesha (Undiksha) is one of the public universities in Bali Province that has implemented distance education, and is currently implementing an online learning system (SPADA) organized by the Ministry of Education and Culture of the Republic of Indonesia. Several courses in the Informatics Engineering Education Study Program have implemented this online learning system, one of which is the Basic Computer System course. Basic Computer Systems is a course that must be taken by students of Information Engineering Education at the beginning of the study period. The Basic Computer Systems course studies materials related to hardware, software, operating systems, open source, and maintenance of hardware and software. Based on the results of observations during the lecture process, conventional media were still used in the lecture process. The term conventional is used in the sense that the learning medias presented are still limited to physical object, learning materials are displayed using the PowerPoint application, and learning objects are taken from the internet. It has implications on the way the lecturer delivers the material using the designed learning media. The media made by lecturers is less integrated, less interactive in terms of use and distribution, and does not get enough attention by students. The results of the observations showed that students were less interested in using the given object. Undiksha already has a place to accommodate its learning object called Undiksha e-Learning. However, the objects in the course are less interactive and poor quality in terms of packaging. Learning objects are still dominated by Portable Document Format (PDF) files, which only convert document files into digital files. This is not enough to produce quality learning objects. An innovative learning media is needed to improve the content contained in Undiksha's e-learning so that it can fulfill the objectives of the Indonesian SPADA Program.

It was found that during the learning process both online and offline in the Basic Computer System course shows that the student response to learning material is low, as indicated by the low average pretest score. Some problems that occur during the learning process in the classroom include: (1) the low enthusiasm of students in participating in learning activities on basic courses in computer systems, so the learning process becomes less effective; (2) students' lack of understanding of the basic knowledge of computer systems so that it impacts the learning process of other subjects that are still related to basic course material of computer systems; and (3) students have lack of understanding of cognitive aspects and skills in learning the basic material of computer systems in the classroom. In an effort to solve some of the above problems, a substantial effort is needed in order to strengthen the cognitive abilities students in the Basic Computer Systems Course.

Based on these problems, the solution that can be offered is to use appropriate technology in developing learning objects. The developed learning objects must have interactive, collaborative, and integrative characteristics. There is application called Articulate Storyline 3. Articulate Story- 
line is a software that can be used to make presentations. Having the same functionality as Microsoft Power Point. Articulate Storyline has several advantages so that it can produce more comprehensive and creative presentations. This software also has features such as timeline, movie, picture, character and can be distributed to various web-based e-learning platforms. This application offers many conveniences in creating learning objects in the form of simulations, quizzes, drag-and-drop interactions, screen recordings, and many other e-learning objects that allow interactions between lecturers, objects, and students. Articulate Storyline 3 can be used to create learning objects that present information in an innovative and interactive format.

Articulate storyline helps digital-based learning modern designers. Darmawan (2016) states that Articulate Storyline is an application supported by simple smart brainware with interactive tutorial procedures to help users format CDs, personal web, and word processing, through templates published both offline and online. According to Pratama (2018), Articulate Storyline is a software that is used as a medium for presentation or communication. It is a multimedia authoring tool used to create interactive learning in the form of a combination of images, text, sound, graphics, video, and animation (Amiroh, 2019, p. 2). The publication of the Articulate Storyline project results is in the form of web-based media that can be run on various devices such as tablets, laptops, and smartphones. Based on the advantages of the articulate storyline application, it is suitable, especially for improving cognitive abilities of the students in basic computer systems courses.

Student competence in the Basic Computer System course in terms of cognitive aspects must increase at the end of the learning process. Cognitive abilities will shape the intellectual abilities and personality students. The structure of cognitive processes in Bloom taxonomic dimension consists of knowledge (C1), understanding (C2), application (C3), analysis (C4), evaluation (C5) and creating (C6) (Krathwohl, 2002, p. 214). The cognitive processes are classified from the simple level of knowledge to the level of creating. Therefore students need to explore and practice their cognitive abilities because cognitive abilities result from thinking activities as the controlling center of human activities.

Higher Order Thinking Skills (HOTS) oriented learning needs to be developed because it can be used as a tool to improve the learning quality and the quality of graduates. According to Burhan and Arifin (2020), the objective of learning is to attain the maximum achievement conforming to the objective. Students should have excellent cognitive abilities and are expected to have a good impact on the surrounding environment. The ability of knowledge and understanding of the basic computer systems course is useful in the daily life of students. With application and analysis skills, students are expected to contribute to the environment they live in and if there are problems related to informatics or computer engineering, they solve those problems. The ability to evaluate and create are needed in providing solutions that are relevant to the development of the computers or informatics in the future.

\section{RESEARCH METHOD}

This study used a descriptive quantitative method with a Pre-Experimental design, namely the One-Group Pretest-Posttest Design. This study only involved one experimental class without a control class. This design compares the conditions before and after of the treatment, namely comparing the pretest value with the posttest value. The research design can be seen in Table 1.

Table 1. Experimental Research Design One-Group Pretest-Posttest

\begin{tabular}{cccc}
\hline Group & Pretest & Treatment & Posttest \\
\hline Experiment & $\mathrm{O}_{1}$ & $\mathrm{X}$ & $\mathrm{O}_{2}$ \\
\hline
\end{tabular}

The stages of research activities are designed based on the design in Table 1. The first stage of this experiment is to provide a pretest to students. The next stage is to provide treatment to students in the experimental group in the form of the application of learning objects based on Articulate Storyline 3 on student cognitive in the Basic Computer Systems course. The experimental activity stage ended by providing a posttest and a response questionnaire to the implementation of the treatment. 
The variables in this study are independent variables and dependent variables. The independent variable is the learning object based on Articulate Storyline 3. The dependent variable is the cognitive abilities of students in basic computer systems courses. In addition, the population in this study were all students in semester 1 of the Informatics Engineering Education study program in Basic Computer Systems courses in the odd semester of the 2020-2021 academic year totaling four classes with a total of 105 students. Furthermore, sample was taken using simple random sampling technique, obtaining Class B as the sample for the experimental group, namely 26 students.

The research instruments used in this study were tests and questionnaires. The test instrument was used to measure students' pedagogical abilities at the pretest and posttest. The form of the test used is objective questions consisting of 30 multiple choice questions done with e-learning aids. Indicators on the question are made by considering the level in the Bloom taxonomy, so the test questions can measure student competencies according to the learning outcomes of their subjects. The questionnaire instrument was used to see student responses on the learning object media based on Articulate Storyline 3 applied during the research. The indicators in the questionnaire were arranged to see the level of implementation and usefulness of the learning object used as the independent variable. The questionnaire consisted of 15 statement items related to the implementation and usefulness of learning objects based on Articulate Storyline 3. The instrument used Likert scale with a range of values as follows: (1) 4 for SS (strongly agree); (2) 3 for S (agree); 2 for TS (disagree); and a value of 1 for STS (strongly disagree). The questionnaire also provides a column for comments and suggestions regarding the implementation of the independent variable treatment.

Data on initial pedagogic abilities of the students were obtained through a pretest. Data on pedagogic ability after the independent variable treatment were obtained through a posttest. Based on these data, data analysis was then carried out to see whether or not there was a significant effect/ difference on the dependent variable before and after the independent variable was treated. In addition, the pretest and posttest scores are also used to see the effectiveness of learning as a result of the treatment of the independent variables.

Hypothesis testing of the effect of independent variables on the dependent variable was carried out using the Paired Sample T-Test. This test is used to compare the posttest results to the pretest results. The assumption test required before carrying out the hypothesis test is the normality test, using the Shapiro-Wilk test. Paired Sample T-Test Hypothesis test can be carried out if the data is normally distributed. If the data is not normally distributed, the hypothesis test is carried out using non-parametric statistics in the form of the Wilcoxon test. Hypothesis testing and assumption tests were carried out with the help of SPSS 17. The Ho from this study is that there is no significant difference on average cognitive abilities of the students between the pretest and posttest.

The effectiveness of using the learning model can be seen: (1) the results of student responses to learning objects based on Articulate Storyline 3 and (2) the results of the calculation of the N-Gain value. The data analysis technique used in the questionnaire results was descriptive analysis. This analysis is used to see the effectiveness of the learning model based on the level of its implementation and usefulness. The results of this analysis are the percentage of the overall response of each student related to the treatment of the independent variables. The formula for calculating the percentage score uses the ideal mean (Mi) and the ideal standard deviation (SDi). The mean $(\bar{x})$ of student response scores was then categorized using the guidelines presented in Table 2.

Table 2. Criteria for Grouping Student Responses

\begin{tabular}{ccc}
\hline No. & Interval & Category \\
\hline 1 & $\mathrm{Mi}+1.5 \mathrm{SDi} \leq \bar{x}$ & Very Positive \\
2 & $\mathrm{Mi}+0.5 \mathrm{SDi} \leq \bar{x}<\mathrm{Mi}+1.5 \mathrm{SDi}$ & Positive \\
3 & $\mathrm{Mi}-0.5 \mathrm{SDi} \leq \bar{x}<\mathrm{Mi}+0.5 \mathrm{SDi}$ & Less Positive \\
4 & $\mathrm{Mi}-1.5 \mathrm{SDi} \leq \bar{x}<\mathrm{Mi}-1.5 \mathrm{SDi}$ & Negative \\
5 & $\bar{x}<\mathrm{Mi}-1.5 \mathrm{SDi}$ & Very Negative \\
\hline
\end{tabular}

The level of effectiveness can be calculated from the N-Gain value. The formula for calculating the N-Gain value can be seen in Formula (1). In addition, the criteria for the N-Gain value can be seen in Table 3 . 
$N-$ Gain $=\frac{\text { Posttest score }- \text { Pretest score }}{\text { Maximum score }- \text { Pretest score }}$.

Table 3. The Criteria for the Gain (Hake, 1999)

\begin{tabular}{cc}
\hline Gain Index & Interpetation \\
\hline $\mathrm{g}>0.70$ & Effective \\
$0.30<\mathrm{g}<0.70$ & Quite Effective \\
$\mathrm{g} \leq 0.30$ & Less Effective \\
\hline
\end{tabular}

\section{RESULTS AND DISCUSSION}

Previous research has produced learning designs. The previous design was developed in the form of a program code using Articulate Storyline 3 (AS 3) as the main medium for learning media. The Dashboard display of learning objects based on Articulate Storyline 3 in the Basic Computer Systems course can be seen in Figure 1, and the Menu display is presented in Figure 2.

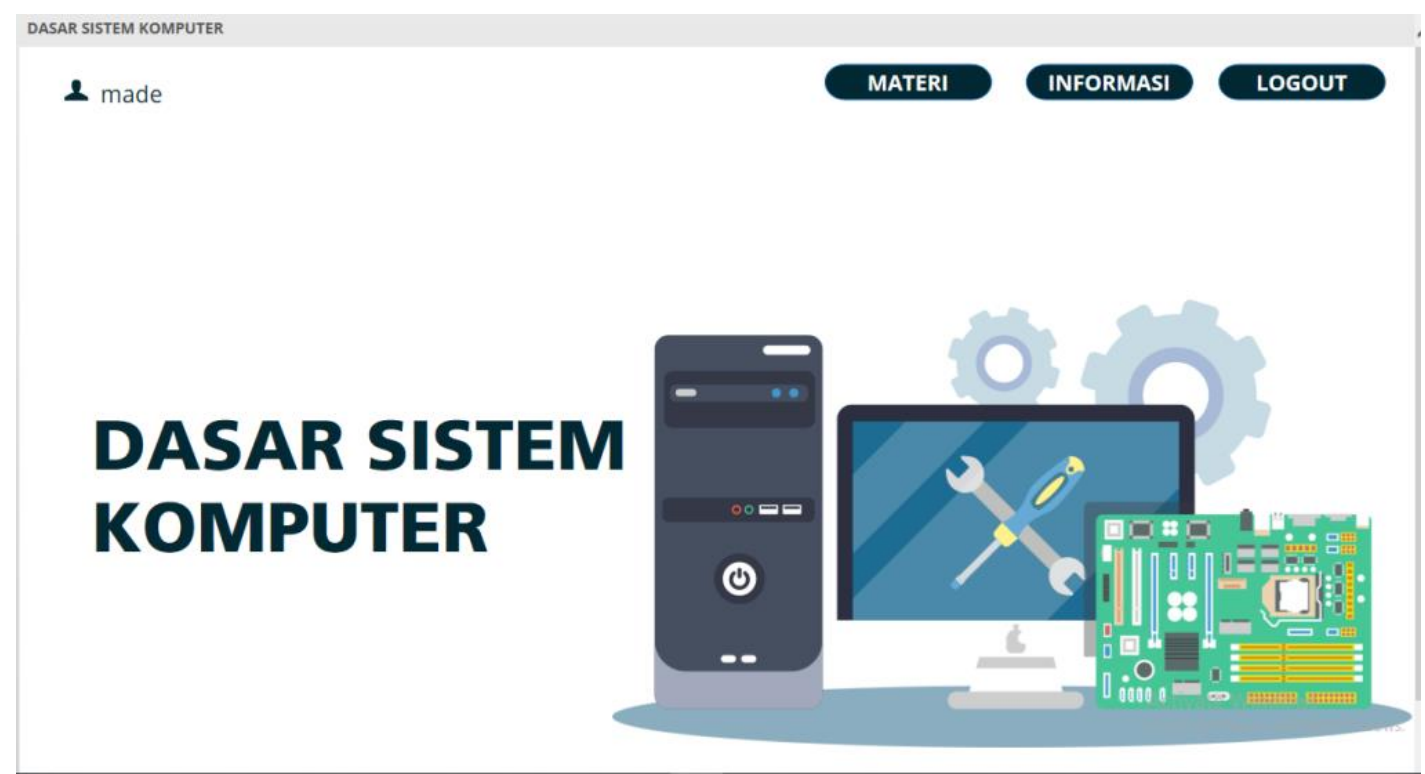

Figure 1. AS3 Learning Object Dashboard of Basic Computer Systems

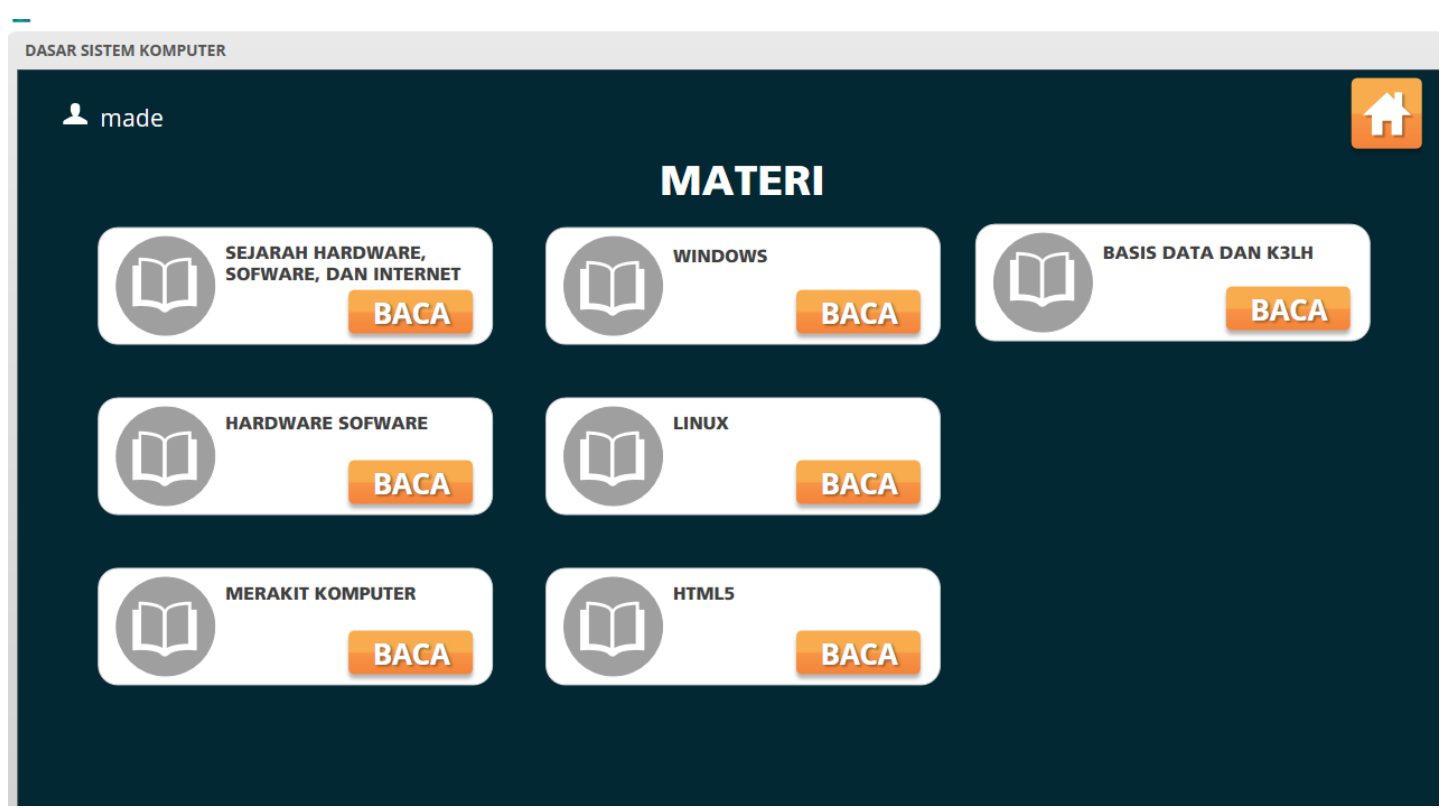

Figure 2. Menu Display of Basic Computer System Materials 
This study aims to determine the effectiveness of learning objects based on Articulate Storyline 3 on student cognitive of the 26 students in the Basic Computer System subject in the Informatics Engineering Education Study Program, Ganesha University of Education. Based on the experimental results, it produces two types of data, including: (a) the results of the pretest and posttest of the students and (b) the results of the student response questionnaires. The data is then processed using descriptive and inferential statistics to see the effect and effectiveness of the application of learning objects based on Articulate Storyline 3.

\section{Effect of Application of Learning Objects}

This experimental research begins with a pretest activity and ends with a posttest activity, using 30 objective questions. The results of the two tests are then processed using descriptive and inferential statistics to determine the effect of the independent variable on the dependent variable. The data contained in Table 4 is the result of descriptive statistical calculations from the results of the pretest and posttest scores.

Table 4. Descriptive Statistical Data of Pretest and Posttest Results

\begin{tabular}{lccccc}
\hline & N & Minimum & Maximum & Mean & Std. Deviation \\
\hline PreTest & 26 & 40 & 75 & 57.12 & 11.504 \\
PostTest & 26 & 65 & 95 & 79.81 & 9.325 \\
Valid N (listwise) & 26 & & & & \\
\hline
\end{tabular}

In Table 4, it can be seen that the pretest mean is lower than the posttest mean. This shows that descriptively there is a difference in the average value of cognitive abilities of the students at the pretest and posttest after the treatment of the application of learning objects based on Articulate Storyline 3. However, this has not shown a significant effect on the application of learning objects based on Articulate Storyline 3 on increasing the cognitive abilities of the student. Furthermore, to determine the significant influence between the two variables, hypothesis testing was carried out using paired sample t-test on the results of the pretest and posttest.

Hypothesis testing can be carried out if the research data is normally distributed. Normally distributed data can be seen from the Normality Test. In this calculation, the researchers used the Shapiro-Wilk Normality Test. The results of the Normality Test can be seen in Table 5.

Table 5. Shapiro-Wilk Normality Test Results

\begin{tabular}{cccc}
\hline Group & Statistic & Df & Sig. \\
\hline Pretest & 0.934 & 26 & 0.095 \\
Posttest & 0.944 & 26 & 0.169 \\
\hline
\end{tabular}

The results of the normality test in Table 5 show the Sig. for the pretest group of 0.095 and the Sig. for the Posttest Group of 0.169. Because the Sig. of the two groups is > 0.05, it can be concluded that the data on cognitive abilities of the students for the pretest and posttest is normally distributed, so that the statistical test can be continued by conducting hypothesis testing using paired sample t-test. The results of the paired sample t-test between the pretest and posttest values can be seen in Table 6 .

Table 6. Result of Pretest dan Posttest t-test

\begin{tabular}{lccc}
\hline & $\mathbf{t}$ & df & Sig. (2-tailed) \\
\hline Equal variances assumed & -7.813 & 50 & 0.000 \\
Equal variances not assumed & -7.813 & 47.947 & 0.000 \\
\hline
\end{tabular}

Based on Table 6, the Sig value, from the results of the paired sample t-test between the pretest and posttest students, the pedagogical ability shows a value of 0.000 . In the paired sample ttest, if the value is Sig. $<0.05$, then Ho is rejected and Ha is accepted. The calculation results show the value of Sig. $0,000<0.05$, it can be ascertained that $\mathrm{Ho}$ is rejected, and $\mathrm{Ha}$ is accepted, so the 
hypothesis taken is that there is a significant difference average between the cognitive abilities of students at the pretest and posttest, which means that there is an effect of implementing learning objects based on Articulate Storyline 3 on cognitive abilities of the students in the Basic Computer Systems Course.

Students experience an increase in cognitive concepts after learning the material of Basic Computer Systems using learning objects based on Articulate Storyline 3. The concept improvement is in accordance with the results of research conducted by Setyaningsih et al. (2020) which concludes that interactive learning media based on Articulate Storyline can improve motivation and learning outcomes of students.

Other relevant research related to the application of interactive multimedia based on Articulate Storyline gave the same results. Previous research by Rafmana et al. (2018) produced similar conclusions, namely that there was a significant effect that interactive multimedia based on Articulate Storylines was valid, practical and having a potential effect on increasing the student learning outcomes motivation. Likewise, Pratama (2018) indicates that there is an increase in the achievement of cognitive learning outcomes and student learning motivation using Articulate Storyline learning media.

\section{Effectiveness of the Application of Learning Objects}

The effectiveness of the application of learning objects based on Articulate Storyline 3 on cognitive abilities of the students is measured from the results of the response questionnaire and the gain value. The response questionnaire is used to see the effectiveness based on the responses given by students to the applied learning object based on Articulate Storyline 3. Meanwhile, the gain value is used to determine the effectiveness of the application of learning objects based on Articulate Storyline 3 which is applied based on the results of the pretest and posttest scores.

The Student Response Test Activity using a response questionnaire was done to 26 students who had previously studied learning objects based on Articulate Storyline 3. The average results of student response scores were categorized using the guidelines in Table 7.

Table 7. Criteria for Classifying Student Responses

\begin{tabular}{ccc}
\hline No & Interval & Category \\
\hline$(1)$ & $(2)$ & $(3)$ \\
1 & $60 \leq 64.19$ & Very Positive \\
2 & $50 \leq 64.19 \leq 60$ & Positive \\
3 & $40 \leq 64.19 \leq 50$ & Less Positive \\
4 & $40 \leq 64.19 \leq 30$ & Negative \\
5 & $64.19<30$ & Very Negative \\
\hline
\end{tabular}

After being converted into the response categorization criteria table, the results of student responses was at the average of 64.19 which is categorized as "Very Positive" qualification range. This shows that the success of learning objects based on Articulate Storyline 3 on student cognitive abilities is already in the criteria of "Very Practical" as evidenced by the results of comments on the questionnaire given such as the joy and motivation of students in using learning objects based on Articulate Storyline 3 and student interest in using learning objects based on Articulate Storyline 3 in the learning process. Based on the results of the response, the students' understanding in the basic course of Computer Systems in terms of cognitive aspects must increase at the end of the learning process. Expectations from the increasing cognitive abilities will shape the intellectual abilities and personality of the students themselves.

In addition to be used in the comparative test to determine the significant effect of learning objects based on Articulate Storyline 3, the pretest and posttest scores in this study were also used to see the effectiveness of learning objects based on Articulate Storyline 3 based on the increase in test scores. Effectiveness is determined based on the calculation of the $\mathrm{N}$-gain value of average pretest and posttest scores of the 26 students. The results of the calculation of the gain value can be seen in Table 8. 
Table 8. Result of Gain Score Calculation

\begin{tabular}{cccc}
\hline Pretest Mean & Posttest Mean & Gain Score & Percentage \\
\hline 57.12 & 79.81 & 0.60 & $60 \%$ \\
\hline
\end{tabular}

Based on the results of the pre-test and post-test analysis, it was obtained an increase in value of 22.69 from the results of the pre-test score of 57.12 to the result of the post-test score of 79.81 . The graph of the average pre-test and post-test results can be seen in Figure 3 .

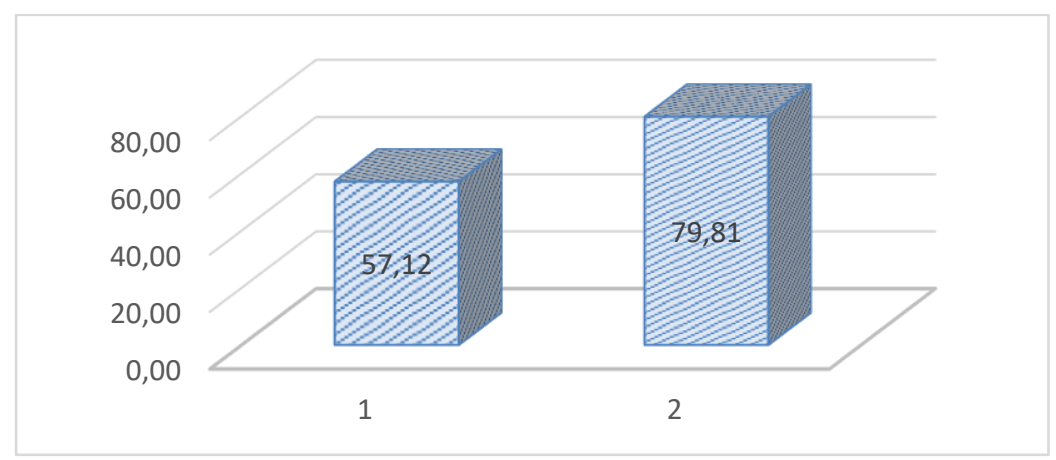

Figure 3. Graph of the Result Pre-test and Post-test

After determining the amount of the increasing value, then the calculation is done to get $\mathrm{N}$ Gain or Normalized Gain, the results obtained from the N-Gain calculation are 0.60 with a percentage of $60 \%$, so that the rate of post-test enhancement is categorized as "Quite Effective" which refers to Table 3. Based on the results obtained, the learning object based on Articulate Storyline 3 has been able to improve cognitive abilities the students in Basic Computer Systems Subjects.

Based on the results obtained, the learning object based on Articulate Storyline 3 has been able to improve the cognitive abilities of students learning outcomes and is effective for use in the learning process of Basic Computer Systems. According to Mudjijo (1995), practicality refers to the level of ease of use as well as the implementation and management of the interpretation of the results. Based on the results of the implementation evaluation, it can be concluded that the learning object based on Articulate Storyline 3 in the Basic Computer System course has met the product quality criteria, namely validity, effectiveness and practicality.

Remembering knowledge will help students in building new knowledge as a cognitive or knowledge strategy process. The analysis showed that the N-Gain calculation based on the pretest posttest test was $60 \%$. Thus, based on the criteria, it is quite effective. Although the criteria is quite effective, the ability of the students to remember must be further improved. The ability to remember, according to Anderson et al. (2001), is a mental cognitive process in retrieving the required knowledge from long-term memory. Recall knowledge is needed to develop meaningful learning processes, solve problems and develop knowledge to the level of understanding and application.

The ability of the students to understand the concept of the basic computer system is seen from the results of the questions given. There are ten multiple choice questions that measure understanding with indicators of achievement in understanding hardware, software and Windows and Linux operating systems. Understanding is a process of thinking and learning to understand. According to Winkel (2004), understanding includes the ability to grasp the meaning of the material being studied. This ability can be used to describe the main content of a reading, change the data presented in a certain form to another form, such as mathematical formulas into words, make predictions about trends that appear in certain data, such as in graphs.

Based on the Bloom Taxonomy dimension, the ability to apply is at the $\mathrm{C} 3$ level. The ability to apply is namely implementing and using procedures in certain situations (Krathwohl, 2002). The ability to apply is applied to six questions with indicators of explaining the concept of database and health and safety. The ability to apply can be improved by applying learning objects based on Articulate Storyline 3 in the learning process. The measurement of the ability to analyze is applied to the indicator explaining the meaning of interaction as many as six items. The problem of analyzing 
ability is given to students in the form of a narrative text related to assembling computers. Based on the results of the analysis, it shows that the ability to analyze is moderate. This can be caused by the inability to link the practicum with the theory of hardware software and Work Safety with the questions being made, so it requires a more in-depth study but the available time is insufficient. In addition, the application of learning strategies is not in accordance with the learning material and there is no habituation to develop cognitive abilities in terms of limited practical hardware installation and lack of practical tools.

\section{CONCLUSION}

Based on the results of the research and data analysis, the following conclusions can be obtained. First, there is a significant effect of the application of learning objects based on Articulate Storyline 3 on cognitive ability in the Basic Computer Systems course. Second, the application of learning objects based on Articulate Storyline 3 is effective to improve the cognitive abilities of the students in the Basic Course of Computer Systems. This conclusion is supported by: (a) The percentage of student responses to the application of learning objects is 64.19 with the qualification "Very Positive". This shows that the success of learning objects based on Articulate Storyline 3 on cognitive abilities of the students is already in the criteria of "Very Practical"; (b) The percentage of the N-Gain value is $60 \%$, which indicates that the learning object is quite effective in improving the cognitive abilities of students in the Basic Computer Systems Course.

\section{ACKNOWLEDGMENTS}

The authors thank the Institute for Research and Community Service of Universitas Pendidikan Ganesha, the Faculty of Engineering and Vocational, and the Department of Informatics Engineering for helping and supporting this research both morally and materially.

\section{REFERENCES}

Amiroh, A. (2019). Mahir membuat media interaktif Articulate Storyline. Pustaka Ananda Srva.

Anderson, L. W., Krathwohl, D. R., Airasian, P.W., Cruikshank, K. A., Mayer, R. E., Pintrich, P. R., \& Wittrock, M. C. (2001). A taxonomy for learning, teaching, and assessing: A revision of Bloom's taxonomy of educational objectives. Longman.

Burhan, N., \& Arifin, Z. (2020). The implementation of block-system learning on the expertise competence of automotive lightweight vehicle engineering in vocational high school. Jurnal Pendidikan Vokasi, 10(1), 80-92. https://doi.org/10.21831/jpv.v10i1.30378

Darmawan, D. (2016). Mobile learning: Sebuah aplikasi teknologi pembelajaran. PT. Raja Grafindo Persada.

Hake, R. R. (1999). Analyzing change/gain scores. Department of Physics, Indiana University.

Krathwohl, D. R. (2002). A revision of Bloom's Taxonomy: An overview. Theory Into Practice, 41(4), 212-218. https://doi.org/10.1207/s15430421tip4104_2

Law of the Republic of Indonesia No. 12 of 2012 concerning Higher Education. (2012). Retrieved from https://lldikti8.ristekdikti.go.id/2019/02/05/undang-undang-republik-indonesia-nomor12-tahun-2012-tentang-pendidikan-tinggi/

Law of the Republic of Indonesia No. 20 of 2003 concerning National Education System. (2003). Retrieved from http://lppks.kemdikbud.go.id/uploads/pengumuman/uu_no_20_tahun_2003. pdf

Mudjijo, M. (1995). Tes hasil belajar. Bumi Aksara. 
Mustofa, M. I., Chodzirin, M., \& Sayekti, L. (2019). Formulasi model perkuliahan daring sebagai upaya menekan disparitas kualitas perguruan tinggi. Walisongo Journal of Information Technology, 1(2), 151-160. http://dx.doi.org/10.21580/wjit.2019.1.2.4067

Pratama, R. A. (2018). Learning media based on Articulate Storyline 2 on Drawing Function Graphs lesson in SMP Patra Dharma 2 Balikpapan. Jurnal Dimensi, 7(1), 19-35. Retrieved from https://www.journal.unrika.ac.id/index.php/jurnaldms/article/download/1631/1187

Rafmana, H., Chotimah, U., \& Alfiandra, A. (2018). Pengembangan multimedia interaktif berbasis Articulate Storyline untuk meningkatkan motivasi belajar siswa pada mata pelajaran PKN kelas XI di SMA Srijaya Negara Palembang. Bhineka Tunggal Ika: Kajian Teori dan Praktik Pendidikan PKN, 5(1), 52-65. Retrieved from https://ejournal.unsri.ac.id/index.php/jbti/ article/view/7898

Regulation of the Minister of Education and Culture No. 109 of 2013 concerning the Implementation of Distance Education in Higher Education. (2013). Retrieved from https://jdih.kemdikbud.go.id/arsip/kepmen_tahun2014_nomor276.pdf

Setyaningsih, S., Rusijono, R., \& Wahyudi, W. (2020). Pengaruh penggunaan media pembelajaran interaktif berbasis Articulate Storyline terhadap motivasi belajar dan hasil belajar siswa pada materi Kerajaan Hindu Budha di Indonesia. Jurnal Pendidikan dan Ilmu Pengetahuan, 20(2), 144-156. Retrieved from http://103.114.35.30/index.php/didaktis/article/viewFile/ $4772 / 2829$

Winkel, W. S. (2004). Psikologi pengajaran. Grasindo. 